\title{
Rice seed germination attributes dried by a recirculating dryer
}

\author{
Efecto de las propiedades de germinación de semillas \\ de arroz secadas mediante secadora de recirculación
}

\author{
Alireza Allameh ${ }^{*}$
}

\begin{abstract}
Using quality seed is a forcible factor in stabilizing agricultural crop production. Rough rice usually has moisture contents over 20 percent during harvest time. Grain respiration and transpiration cause seed deterioration and make it vulnerable to microorganisms, insects, and other pests. Hence, grain moisture content has to be kept at a certain level to maintain seed quality. An appropriate drying air temperature should dry Rough rice to a desired final moisture content. In this study, newly harvested paddy (Hashemi cultivar) was dried by a recirculating dryer with three drying air temperatures $\left(37,42\right.$, and $\left.48^{\circ} \mathrm{C}\right)$ until two final moisture contents (12 and 14\% w.b.). The effect of parameters was examined on seed germination characteristics (i.e., germinability, mean germination rate, germination energy, and seedling vigor index). The results revealed that drying air temperature and the final seed moisture content affected germinability and seedling weight vigor index significantly $(\mathrm{p}<0.01)$. Seedling length vigor index and germination energy were only influenced by drying air temperature $(\mathrm{p}<0.01)$. The highest seed germinability $(80 \%$ averagely $)$ was acquired when the seed dried by drying air temperature of $37^{\circ} \mathrm{C}$ to the final moisture content of $14 \%$. The mean germination rate was not affected by those factors. The maximum seedling length vigor index (16262) observed while drying air temperature was $37^{\circ} \mathrm{C}$. The highest seedling weight vigor index (8.186) was obtained when the seed was dried by an air temperature of $37^{\circ} \mathrm{C}$ up to $14 \%$ final moisture content. The maximum germination energy $(68.7 \%)$ belonged to samples treated by drying air temperature of $37^{\circ} \mathrm{C}$ up to $14 \%$ final moisture content. Altogether, optimum seed drying is achieved in the drying air temperature of $37^{\circ} \mathrm{C}$ up to $14 \%$ final moisture content.
\end{abstract}

Keywords: rice, seed, drying, grain moisture content, germination.

\section{RESUMEN}

El uso de semillas de calidad es un factor decisivo para garantizar la producción agrícola. Al momento de la cosecha, el arroz suele tener un contenido de humedad superior al 20\%. Este contenido de humedad de los granos provoca el deterioro de las semillas y las hace vulnerables a microorganismos, insectos y otras plagas. Por lo tanto, el contenido de humedad del grano debe mantenerse a un cierto nivel para preservar la calidad de la semilla. Durante el proceso de secado se requiere una temperatura de aire de secado adecuada hasta el contenido de humedad final deseado. En este estudio, los granos de arroz recién cosechados (cultivar Hashemi) se secaron mediante una secadora de recirculación con tres temperaturas de aire $\left(37,42\right.$ y $\left.48^{\circ} \mathrm{C}\right)$ hasta dos contenidos de humedad finales (12 y $14 \%$ b.h.). Se evaluó el efecto de los tratamientos en parámetros de germinación de las semillas (capacidad de germinación, tasa media de germinación, energía de germinación e índice de vigor de las plántulas). Los resultados sugieren que la temperatura del aire de secado y el contenido de humedad final de la semilla afectaron significativamente la capacidad de germinación y el índice de vigor del peso de la plántula $(p<0,01)$. El índice de vigor de la longitud de las plántulas y la energía de germinación solo fueron influenciados por la temperatura del aire de secado $(p<0,01)$. La germinabilidad más alta de la semilla ( $80 \%$ en promedio) se observa cuando la semilla se seca a una temperatura del aire de $37{ }^{\circ} \mathrm{C}$ hasta un contenido de humedad final del $14 \%$. La tasa media de germinación no se vio afectada por esos factores. El índice máximo de vigor de longitud de plántula (16262) se obtiene con temperatura de secado a $37^{\circ} \mathrm{C}$. El índice de vigor de peso de plántula más alto (8.186) se logró cuando la semilla se secó a una temperatura del aire de $37^{\circ} \mathrm{C}$ hasta un contenido de humedad final del $14 \%$. La energía máxima de germinación (68,7\%) correspondió a las muestras tratadas con una temperatura del aire de secado de $37^{\circ} \mathrm{C}$ hasta un contenido de humedad final del 14\%. En general, la condición óptima de secado de semillas se obtiene con temperatura de secado de $37^{\circ} \mathrm{C}$ hasta un contenido de humedad final del $14 \%$.

Palabras clave: arroz, semilla, secado, contenido de humedad en grano, germinación.

\footnotetext{
1 Rice Research Institute of Iran, Agricultural Research, Education and Extension Organization (AREEO), Rasht, Iran.

* Corresponding author: a.allameh@areeo.ac.ir
}

Fecha de Recepción: 22 de septiembre, 2020.

Fecha de Aceptación: 5 de diciembre, 2020. 


\section{Introduction}

Rice cultivation sustainability is directly dependent on the quality seed. The good seed is considered one of the main inputs in agriculture, which affects productivity intensely. Various parameters contribute to quality seed production, including agronomic characteristics of a cultivar, soil and plant nutrition, plant protection, harvest, and postharvest operations. Condoning any of these may lead to severe degradation of seed quality.

Apart from the ultimate use of paddy (seed or consumption), reducing grain moisture content has an imperative and impressive role in its quality and quantity. Seeds obtained in this way will have higher functionality. The amount of such an increase is directly proportional to the quality of the sown seed. In the seed production industry, the focus lies on high-quality seed production to raise crop yield. A feeble seed, in the first instance, will start evanescently. Plants will often suffer from low transplanting strength, poor growth, heterogeneity in maturity and plant height, weed competition weakness, insects, pests, diseases, and intolerability to bad weather conditions at the first stage of the plantation. Thus, the quality and quantity of the grain will fall eventually. Low milling recovery of paddy gives evidence of a poor seed (Asea et al., 2010).

Rough rice drying takes place in various ways in which all of them aim to lower grain moisture content to a suitable level. Drying air temperature and the final moisture content determine seed quality. Therefore, drying conditions needs to be arranged, so that seed germination ability stays unscathed. Somado et al. (2006) assessed the effect of some drying methods on moisture content and viability of rice seeds. They stated that sun drying would be an efficient way for short-term storage at the farm. Yari et al. (2012) studied thermal hardening's effect on two rice seed cultivars' germination. They suggested that chilling, followed by heating of seeds, had better results regarding germination capacities. Hassan et al. (2014) dried hybrid rice seeds as a thin layer with different air temperatures. They reported that the highest germination capacity was achieved when seeds dried by an air temperature of $40{ }^{\circ} \mathrm{C}$. In Iran, rice seeds are dried in different ways as stacked, sun-dried in the field, and a batch in-bin drying. This study was conducted to assess a recirculating dryer's potential for rice seed drying by determining appropriate drying air temperature and the final moisture content to retain seed germination capacity.

\section{Materials and methods}

The experiments were conducted at Rice Research Institute of Iran (RRII), Rasht, Iran, in 2018. Crop harvesting performed using a wholecrop rice combine harvester. Grain moisture content was about $18-20 \%$ (w.b.), which was measured by a portable moisture meter (GMK, RS303, Korea). Then, grains were sacked in $60 \mathrm{~kg}$ bags and transferred to the drying facility. Rough rice was dried by a recirculating dryer (Shalichai Co., Iran). In each run, 2 tons of rough rice was dried by the dryer. The drying period had been adjusted on 105 minutes' intervals, and rough rice was automatically recirculated within 15 minutes from bottom to top of the dryer. Three drying air temperatures of 37,42 , and $48{ }^{\circ} \mathrm{C}$ were utilized for drying tests. When the average moisture content dropped to the final moisture contents of 14 , and 12 percent, three samples of $1 \mathrm{~kg}$ were taken and placed in sealed bags. By completing the drying process, seed germination tests were commenced according to the International Seed Testing Association (ISTA) rules.

At first, seed dormancy was broken. 50 rice seeds were placed in a petri dish, soaked in distilled water, and settled in a preheated incubator at $50{ }^{\circ} \mathrm{C}$ with a relative humidity of $95 \%$ for 24 hours. This accelerated rice seed aging. After that, seeds were ready for germination tests. Here, the method of blotting paper rolling was used. Those 50 seeds from each petri dish laid on the blotting paper and covered by another layer. Then, they were moistened with distilled water and rolled. All rolls were set orderly inside a plastic capped container. Finally, the container was placed in a germinator (GER SET 550G, Grouk Co., Iran) adjusted on $25^{\circ} \mathrm{C}$ and $42 \% \mathrm{RH}$. Seed samples were checked daily, and their changes were recorded in terms of the number of seeds germinated, root, and shoot growth. According to ISTA rules, a seed is considered germinated when its husk is torn, root, and shoot emerged and lengthened more than $2 \mathrm{~mm}$. All measurements were kept till day $14^{\text {th }}$, and on that day, the final counting of germinated seeds and root and shoot length was completed. 
Then, from each sample, 15 intact germinated seeds were randomly selected, and after removing their moisture with blotting paper, they weighted and recorded. Those samples were dried by an oven set at $70^{\circ} \mathrm{C}$ for $48 \mathrm{~h}$. Then, their dried weight was recorded. The following formulae were used to compute the intended traits (Ranal et al., 2009; Islam et al., 2012; Vibhuti et al., 2015):

$$
\begin{gathered}
\mathrm{G}=\frac{\mathrm{n}_{\mathrm{i}}}{\mathrm{N}} \times 100 \\
\mathrm{MGR}=\frac{\sum_{\mathrm{i}=1}^{\mathrm{k}} \mathrm{n}_{\mathrm{i}}}{\sum_{\mathrm{i}=1}^{\mathrm{k}} \mathrm{n}_{\mathrm{i}} \mathrm{t}_{\mathrm{i}}} \\
\mathrm{SVI}_{\mathrm{L}}=\mathrm{G} \times \mathrm{MSL} \\
\mathrm{SVI}_{\mathrm{W}}=\mathrm{G} \times \mathrm{MSW} \\
\mathrm{GE}=\mathrm{G}_{3}
\end{gathered}
$$

In which, G: the germination percentage (\%), $\mathrm{n}_{\mathrm{i}}$ : number of seeds germinated in the $\mathrm{i}^{\text {th }}$ time, $\mathrm{N}$ : total seeds set in each test, MGR: mean germination rate, $\mathrm{t}_{\mathrm{i}}$ : time from the start of the experiment to the $\mathrm{i}^{\text {th }}$ observation, $\mathrm{k}$ : last time of germination, $\mathrm{SVI}_{\mathrm{L}}$ : seedling vigor index (length), MSL: mean seedling length, $\mathrm{SVI}_{\mathrm{W}}$ : seedling vigor index (weight), MSW: mean seedling weight, GE: germination energy $(\%), \mathrm{G}_{3}$ : germination percentage in the $3^{\text {rd }}$ day. The germination percentage data was transformed to $\arcsin \sqrt{(100 / x)}$ (Aminul Islam et al., 2013).

A factorial design was laid out in a completely randomized design (CRD) with three replications to study the different drying parameters' effect on seed germination features. Independent variables included the drying air temperature (at three levels of 37, 42, and $48^{\circ} \mathrm{C}$ ) and the final moisture content (at two levels of 12 and 14 percent). The dependent variables were seed germination percentage, mean germination rate, seedling vigor index (length), seedling vigor index (weight), and germination energy. The acquired data were then analyzed by SAS 9 software.

\section{Results and discussion}

\section{The drying air temperature effect}

In Table 1, the means of comparison of tested traits have been shown under different drying air temperatures. It can be seen that there is a significant difference between the drying air temperature of $37^{\circ} \mathrm{C}$ and others. Seed germination percentage and germination energy differed significantly in terms of selected drying air temperatures. Both $\mathrm{SVI}_{\mathrm{L}}$ and $\mathrm{SVI}_{\mathrm{W}}$ did not represent any significant difference when dried by the drying air temperatures of 42 and $48{ }^{\circ} \mathrm{C}$. The highest seed germination percentage (80\%) observed when seeds dried by the drying air temperature of $37{ }^{\circ} \mathrm{C}$ until the final moisture content of $14 \%$ (Figure 1). Also, the lowest seed germination percentage (55\%) obtained while seeds dried by the drying air temperature of $48^{\circ} \mathrm{C}$ till the final moisture content of $12 \%$. The maximum and minimum germination energy (68.7 and $46 \%$ ) were related to the drying air temperatures of 37 and $48^{\circ} \mathrm{C}$, respectively, at the final moisture content of $14 \%$ (Figure 2). Some scientists have pointed out that the drying air temperature affects germination. Elepano et al. (2005) reported that for seed purposes, the drying air temperature has to be less than $60^{\circ} \mathrm{C}$. Jittani et al. (2010) mentioned that the drying air temperature needs to be selected carefully. They stated that safe rice seed drying could be achieved by the drying air temperature of $40^{\circ} \mathrm{C}$. Hassan $\mathrm{et} \mathrm{al}$. (2014) found out that the maximum seed germination would be in the drying air temperature of $40^{\circ} \mathrm{C}$ and temperature increase led to a significant decrease in germination. Gill et al. (2014) have also expressed that deep bed drying would not hurt seeds so long as the drying air temperature selected on $38^{\circ} \mathrm{C}$.

Table 1. Variations of traits tested under drying air temperature.

\begin{tabular}{ccccc}
\hline \multirow{2}{*}{ Drying air temperature $\left({ }^{\circ} \mathrm{C}\right)$} & \multicolumn{4}{c}{ Traits tested } \\
\cline { 2 - 5 } & Germination $(\%)$ & $\mathrm{SVI}_{\mathrm{L}}$ & $\mathrm{SVI}_{\mathrm{W}}$ & Germination energy (\%) \\
\hline 37 & $77^{\mathrm{a}}$ & $16262.8^{\mathrm{a}}$ & $7.67^{\mathrm{a}}$ & $65.35^{\mathrm{a}}$ \\
42 & $65^{\mathrm{b}}$ & $12800.3^{\mathrm{b}}$ & $5.74^{\mathrm{b}}$ & $52.70^{\mathrm{b}}$ \\
48 & $57^{\mathrm{c}}$ & $11679.8^{\mathrm{b}}$ & $5.42^{\mathrm{b}}$ & $46.35^{\mathrm{c}}$ \\
\hline
\end{tabular}

In each column, figures having the same letter are not significant at $1 \%$ level. 


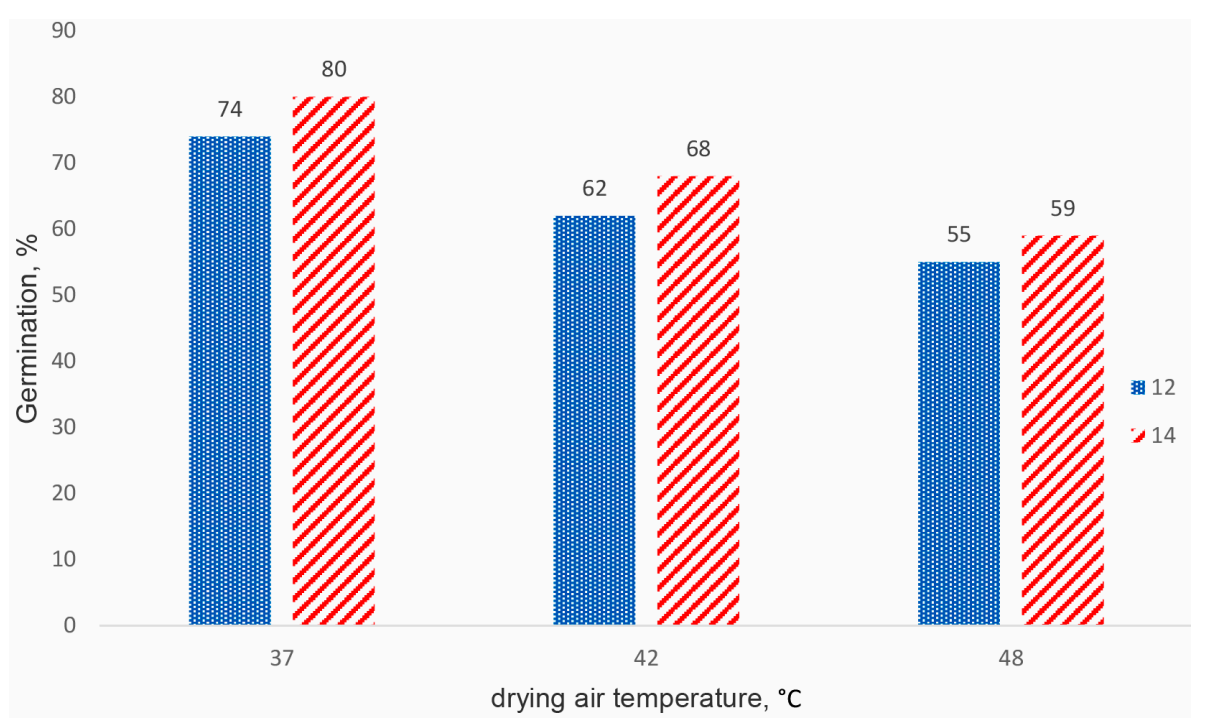

Figure 1. Variations of germination under drying air temperature and the final seed MC

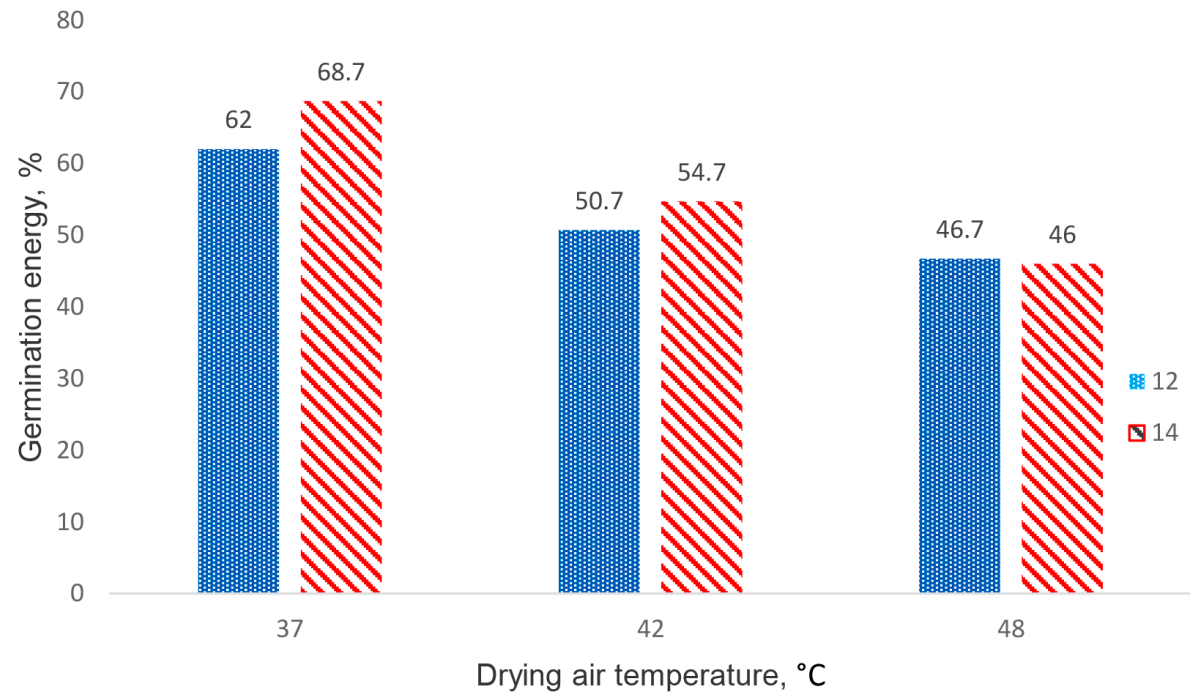

Figure 2. Variations of germination energy under drying air temperature and the final MC

In Figure 3, variations of $\mathrm{SVI}_{\mathrm{L}}$ has been illustrated as a function of the drying air temperature and the final seed moisture content. This index is the maximum when seeds are dried by the drying air temperature of $37^{\circ} \mathrm{C}$, while the minimum obtains at the drying air temperature of $48^{\circ} \mathrm{C}$. Since there is a direct relationship between $\mathrm{SVI}_{\mathrm{L}}$ and germination percentage, $\mathrm{SVI}_{\mathrm{L}}$ will decrease due to an increase in the drying air temperature, leading to a lower germination percentage.

Such a circumstance was observed for $\mathrm{SVI}_{\mathrm{W}}$. Samples dried by the drying air temperature of $37^{\circ} \mathrm{C}$ had significant differences $(\mathrm{p}<0.01)$ with dried seeds in 42 and $48^{\circ} \mathrm{C}$. There was no significant difference among 42 and $48^{\circ} \mathrm{C}$. The highest $\mathrm{SVI}_{\mathrm{W}}$ (8.186 on average) was related to samples dried by the drying air temperature of $37^{\circ} \mathrm{C}$ until the final moisture content of $14 \%$. In contrast, the lowest amount belonged to seeds dried by the drying air temperature of $48^{\circ} \mathrm{C}$ till the final moisture content of $12 \% . \mathrm{SVI}_{\mathrm{W}}$ has a direct relationship with dry seedling mass. The more seeds dry, the more water removal will be, and this causes water tension inside seeds. Additionally, seeds will be longer exposed to the drying air, which 


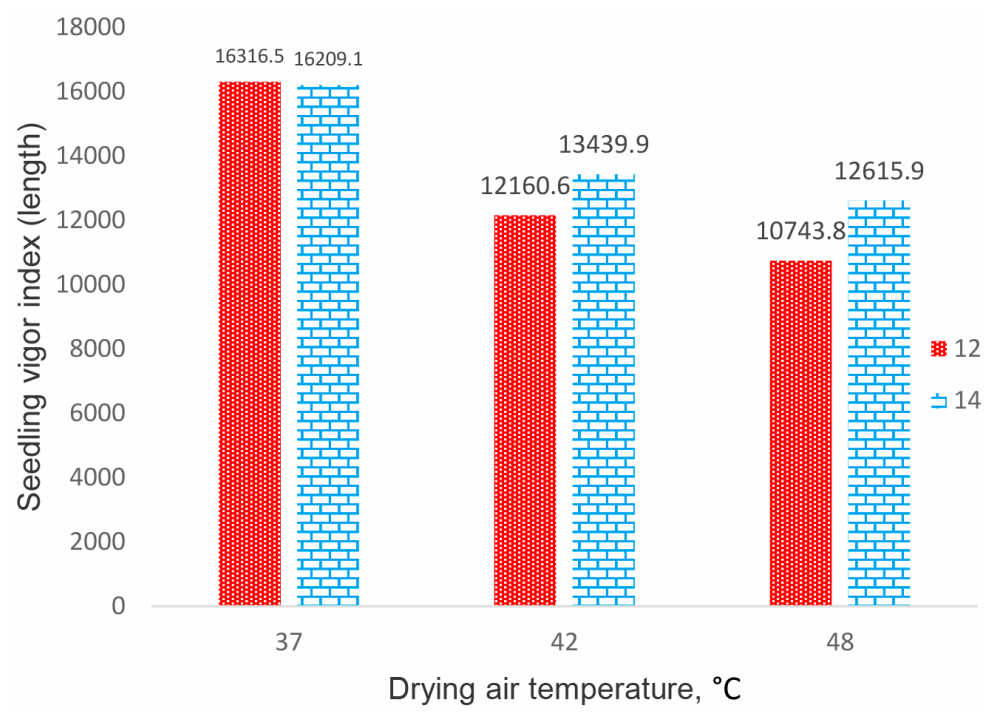

Figure $3 . \mathrm{SVI}_{\mathrm{L}}$ variations under drying air temperature and the final MC.

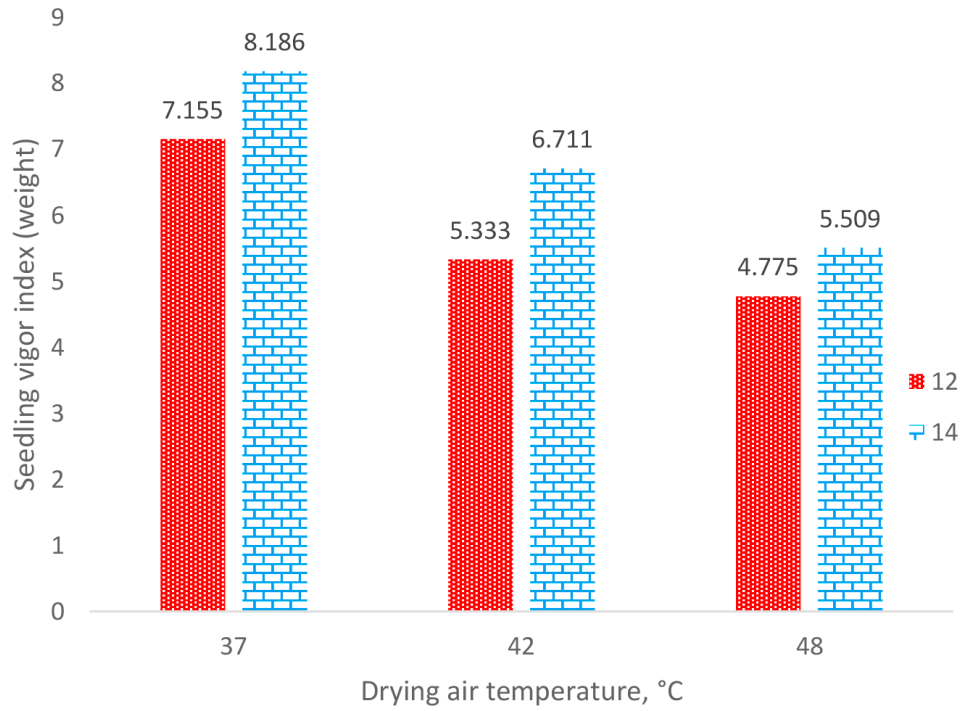

Figure $4 . \mathrm{SVI}_{\mathrm{W}}$ variations under drying air temperature and the final $\mathrm{MC}$

tends to create thermal tension and debilitation or fatality of the embryo. Khan et al. (2017) have also expressed that temperature accounted for abiotic stress, which affected rice genotypes' physiological and morphological characteristics. They studied seed decline in different temperatures $(25,35$, and $45^{\circ} \mathrm{C}$ ) and intervals $(36,72$, and $96 \mathrm{~h}$ ) and found out ultimately that physiological features such as germination percentage, root and shoot length, root and shoot dry mass were significantly affected by thermal tension.

\section{Final seed moisture content effect}

This effect has only impressed two traits of germination percentage and $\mathrm{SVI}_{\mathrm{W}}$ significantly $(p<0.01)$. The longer seeds are exposed to hot drying air, the more they become dehydrated. In this way, seeds lose their inner water excessively. Both of these conditions impose aquatic and thermal tensions on seeds. Losing moisture content and long-term drying process accounts for seed viability decline and even embryo fatality in aggravating circumstances. 


\section{Conclusions}

Based on the experiments and data analysis, the results could be summarized as follows:

- In the case of applying a recirculating dryer for rice seed drying, the drying air temperature must not exceed the allowable limit $\left(37^{\circ} \mathrm{C}\right)$; Otherwise, seed viability would decline severely.

- For tested cultivar in this study, it is recommended that seeds would dry by the ultimate air temperature of $37^{\circ} \mathrm{C}$ until the final moisture content of $14 \%$.

\section{Acknowledgment}

This work was part of a research project conducted at Rice Research Institute of Iran under the approval code of 2-04-04-027-950621. The author would like to express his gratitude for their financial and administrative supports.

\section{Literature cited}

Aminul Islam, A.K.M.; Anvar, N.; Yaakub, Z.; Ghani, J.A.; Osman M

2013. Combining ability for germination traits in Jatropha curcas L. The Scientific World Journal. 1-6, Article ID 935981.

Asea, G.; Onaga, G.; Phiri, N.A.; Karanja, D.K.

2010. Rice seed production manual. National Crops Resources Institute (NaCRRI) and CABI Africa. $86 \mathrm{p}$.

Elepano, A.R.; Billante, R.D.; Drahousky, I.B.

2005. Two-stage drying as a different strategy for paddy rice. Philippine Journal of Crop Science, 30(1): 3-9.

Gill, R.S.; Singh, S.; Sing, P.P.

2014. Design and development of desiccant seed dryer with airflow inversion and recirculation. Journal of Food Science and Technology, 51(11): 3418-3424.

Hassan, A.A.M.; Bala, B.K.; Rowshan, M.K.

2014. Thin layer drying of hybrid rice seed. Engineering in Agriculture, Environment and Food, 7(4): 169-175.

Islam, R.; Mukherjee, A.; Hossin, M.

2012. Effect of osmopriming on rice seed germination and ISTA. seedling growth. J. Bangladesh Agri. Uni., 10(1): 15-20.

2016. International rules for seed testing. The International Seed Testing Association (ISTA) Zürichstr. 50, CH-8303 Bassersdorf, Switzerland.

Jittani, W.; Srzednicki, G.; Driscoll, R.

2010. Corn, rice and wheat drying by two-stage concept. Drying Technology: An International Journal, 28(6): 807-815.
Khan, A.; Ali M.; Siddiqui, S.U.; Jatoi, S.A.; Jan, S.A.; Khan, N.; Ghafoor, A.

2017. Effect of various temperatures and duration on deterioration of rice seeds. Science, Technology and Development, 36(2): 79-83.

Ranal M.A., Santana D.G., Ferreira W.R.; Rodrigues C.M. 2009. Calculating germination measurements and organizing spreadsheets. Revista Brasil. Bot., 32(4): 849-855.

Somado E.A., Sanchez I.M., Nwilene F., Sie M., Ogunbayo A.A., Sanni K.; Tia K.S.

2006. Comparative studies of drying methods on the seed quality of interspecific NERICA rice varieties (Oryza Glaberrima X Oryza Sativa) and their parents. African Journal of Biotechnology, 5(18): 1618-1624.

Thai T.Y.; Daud S.M.

1982. The effects of sun and oven-drying on the germination and storability of rice (Oryza Sativa L.) seeds. MARDI Res. Bull., 10(2): 131-137.

Vibhuti G., Shahi C., Bargali K.; Bargali S.S.

2015. Seed germination and seedling growth parameters of rice (Oryza Sativa) varieties as affected by salt water stress. Indian Journal of Agricultural Sciences, 85(1): 102-108.

Yari L., Zareyan A., Sheidaei S.; Khazaei F.

2012. Influence of high and low temperature treatments on seed germination and seedling vigor of rice (Oryza Sativa L.). World Applied Sciences Journal, 16(7): 1015-1018. 